\title{
PENINGKATAN PRODUKSI BIOMASSA CHLORELLA VULGARIS MELALUI PERLAKUAN TEKNIK PEMERANGKAPAN SEL DALAM ALIRAN SIRKULASI MEDIA KULTUR
}

\author{
Dianursanti*, Rachma Nuzulliany, Anondho Wijanarko, dan M. Nasikin \\ Departemen Teknik Kimia, Fakultas Teknik, Universitas Indonesia \\ Kampus Baru UI Depok 16424 \\ Email: danti@che.ui.ac.id
}

\begin{abstract}
Abstrak
Belakangan ini, Chlorella vulgaris diminati oleh para ahli untuk diteliti karena kemampuannya sebagai penghasil biomassa yang bermanfaat sebagai suplemen makanan dan kesehatan. Dalam proses pembudidayaannya, Chlorella vulgaris ini dapat dimanfaatkan sebagai pereduksi pemanasan global. Chlorella vulgaris dapat dengan efisien mereduksi $\mathrm{CO} 2$ karena mereka dapat tumbuh dengan cepat dan mudah diadaptasikan ke dalam rekayasa sistem fotobioreaktor. Pencahayaan yang diberlakukan pada penelitian ini adalah pencahayaan kontinu dengan intensitas 5000 lux. Namun, pencahayaan ini memiliki keterbatasan karena intensitas yang diberikan selalu konstan padahal jumlah Chlorella vulgaris dalam kultur semakin meningkat. Oleh sebab itu, salah satu upaya yang dapat dilakukan untuk mengatasinya adalah dengan menggunakan proses pemerangkapan sel atau filtrasi. Proses Kultivasi Chlorella vulgaris dilakukan dalam fotobioreaktor kolom gelembung skala menengah yang dialiri oleh udara yang mengandung $5 \% \mathrm{CO}_{2}$ dengan laju alir sebesar $15,66 \mathrm{~m} / \mathrm{jam}$. Proses filtrasi untuk kultivasi Chlorella vulgaris berhasil meningkatkan produksi biomassanya hingga 1,03 kali lipat dibandingkan dengan pencahayaan kontinu tanpa filtrasi dengan jumlah inokulum yang sama. Hasil akhir produksi biomassa adalah $0,00756 \mathrm{~g} / \mathrm{dm}^{3}$ dengan masa kultivasi yang lebih singkat yaitu selama 200 jam.
\end{abstract}

Keywords: filtrasi, Chlorella vulgaris., pencahayaan kontinu, fotobioreaktor kolom gelembung, fiksasi $\mathrm{CO}_{2}$.

\begin{abstract}
Recently, Chlorella vulgaris is widely studied by experts for its ability as a food supplement and health. Cultivation of Chlorella vulgaris can be used as a tool to reduce global warming. Chlorella vulgaris can efficiently reduce $\mathrm{CO}_{2}$ because they can grow quickly and easily adapted into the photobioreactor system engineering. This research uses continuous illumination of 5000 lux. However, this lighting condition has limitations because of the intensity given is always constant while the number of Chlorella vulgaris in culture increased. Therefore, one solution to solve it is by using the entrapment of cell or filtration process. Chlorella vulgaris cultivation process carried out in bubble column photobioreactor medium flowed by air containing 5\% CO2 with a flow rate of $15.66 \mathrm{~m} / \mathrm{hr}$. The process of Chlorella vulgaris cultivation with filtration technique has successfully increased production of biomass up to 1.03 times compared with continuous lighting without filtration with the same amount of inoculum. The final result of dry weight biomass obtained was $0.00756 \mathrm{~g} / \mathrm{dm}^{3}$ with shorter cultivation period, 200 hours.
\end{abstract}

Keywords: filtration, Chlorella vulgaris., constant lighting intensity, bubble column photobioreactor, $\mathrm{CO}_{2}$ fixation.

${ }^{*}$ korespondensi 


\section{Pendahuluan}

Karbondioksida merupakan gas tidak berwarna yang terdapat pada atmosfer dengan jumlah mencapai 330 ppm dan paling banyak berasal dari pembakaran bahan bakar fosil (Wijanarko dkk., 2006). Peningkatan emisi gas rumah kaca ini menyebabkan efek pemanasan global yang ditandai dengan naiknya suhu atmosfer dan iklim yang tidak stabil.

Berbagai upaya telah dilakukan sebagai langkah untuk mengatasi pemanasan global tersebut, di antaranya adalah dengan mengembangkan penelitian-penelitian di bidang bioteknologi. Inovasi yang ramai diperbincangkan saat ini adalah pemanfaatan mikroalga untuk memfiksasi $\mathrm{CO}_{2}$ melalui proses fotosintesis. Salah satu mikroalga tersebut adalah Chlorella vulgaris.

Efisiensi fotosintesis pada Chlorella vulgaris mencapai $8 \%$ dan kandungan klorofilnya mencapai 28,9 $\mathrm{g} / \mathrm{kg}$ berat biomassa, paling tinggi jika dibandingkan dengan seluruh mikroalga hijau bahkan tumbuhan tingkat tinggi di dunia. Oleh karena itu, Chlorella vulgaris dapat memfiksasi $\mathrm{CO}_{2}$ dalam jumlah yang sangat besar. Kemampuan inilah yang secara tidak langsung berdampak positif terhadap penurunan efek pemanasan global.

Selama berfotosintesis, Chlorella vulgaris mempunyai kemampuan untuk tumbuh dan berkembangbiak dengan cepat. Oleh karena itu, selain menguntungkan dalam penurunan efek pemanasan global, pertumbuhan Chlorella vulgaris juga memberikan efek ganda yaitu menghasilkan produksi biomassa dalam jumlah yang tinggi. Biomassa dari Chlorella vulgaris banyak mengandung vitamin, karbohidrat, dan terutama protein sehingga mempunyai potensi secara komersial untuk dimanfaatkan sebagai suplemen makanan (Becker, 2004; Wirosaputro, 2002).

Mengingat banyaknya manfaat Chlorella vulgaris, perlu dilakukan studi lebih lanjut tentang pembudidayaan mikroalga ini agar didapatkan hasil yang optimal. Variabel penting yang perlu diperhatikan dalam pembudidayaan Chlorella vulgaris adalah pencahayaan. Pencahayaan yang tidak baik dapat menyebabkan efek self-shading yaitu peristiwa penutupan satu sel oleh sel lain akibat tidak meratanya cahaya dan $\mathrm{CO}_{2}$ yang didapatkan oleh alga. Baik buruknya factor pencahayaan juga sangat berkaitan dengan perancangan atau desain dari sistem fotobioreaktor yang digunakan (Pulz dan Scheibenbogen, 1998). Di Departemen Teknik Kimia Universitas Indonesia telah dilakukan berbagai penelitian dengan optimasi pencahayaan untuk meningkatkan produksi biomassa Chlorella vulgaris, yaitu dengan pencahayaan terang-gelap, kontinu, dan alterasi. Hasil penelitian dengan pencahayaan alterasi pada skala lab menunjukkan bahwa alterasi pencahayaan menunjukkan produksi biomassa 1,61 kali lebih tinggi dibandingkan dengan

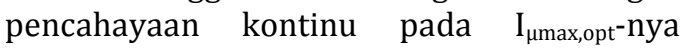
dengan jumlah inokulum yang sama yaitu sebesar $16 \mathrm{~g} / \mathrm{dm}^{3}$ dengan masa kultivasi lebih singkat 220 jam (Wijanarko dkk., 2005). Hasil tersebut diperkuat dengan penelitian pada skala menengah dengan jenis pencahayaan yang sama, yang menunjukkan bahwa pencahayaan alterasi memberi produksi biomassa sekitar 1,63 kali lebih tinggi dibandingkan dengan pencahayaan kontinu (Wijanarko dkk., 2006).

Kedua hasil tersebut menunjukkan bahwa pencahayaan kontinu memiliki keterbatasan karena jumlah sel akan selalu meningkat dalam media kultur namun tidak diimbangi dengan peningkatan intensitas seperti yang dilakukan pada pencahayaan alterasi. Oleh karena itu, selain dari segi pencahayaan, optimasi untuk menghindari efek self-shading pada perlakuan pencahayaan kontinu juga dilakukan dengan metode lain. (Wijanarko dkk., 2003)

Pada penelitian kali ini, metode baru yang akan dilakukan adalah penggunaan proses pemerangkapan sel pada kultivasi Chlorella vulgaris, yang bertujuan memerangkap sebagian biomassa dalam kultur untuk mengurangi kepadatan sehingga intensitas cahaya yang selalu konstan tetap dapat mencukupi pada kultivasi. Teknik pemerangkapan sel ini dilakukan dengan memberikan alat filter berupa sponge (busa) ke dalam fotobioreaktor. Dengan demikian istilah yang digunakan untuk penamaan sistem ini adalah fotobioreaktor yang berfilter dan tidak berfilter.

Penelitian kali ini merupakan scale-up dari penelitian-penelitian sebelumnya. Hasil yang diperoleh diharapkan dapat dijadikan acuan dalam penelitian-penelitian selanjutnya, dalam mengoptimalkan produksi biomassa Chlorella vulgaris dalam skala besar. 


\section{Metodologi}

Pada penelitian ini, digunakan strain Chlorella vulgaris sebagai objek penelitian yang merupakan ganggang bersel tunggal yang didapat dari Balai Penelitian Perikanan Air Tawar Depok. Penelitian ini menggunakan fotobioreaktor kolom gelembung tembus cahaya skala menengah bervolume $18 \mathrm{~L}$ dengan ukuran reaktor (38.5 x $10 \times 60) \mathrm{cm}^{3}$, yang dilengkapi dengan alat filter. Suhu yang digunakan merupakan suhu ruang, kecepatan superfisial udara sebesar $15.66 \mathrm{~m} / \mathrm{jam}$, dan konsentrasi $\mathrm{CO}_{2}$ yang diberikan sebesar $5 \%$ dari udara. Sebagai pembanding, dilakukan penelitian dengan kondisi yang sama namun tanpa perlakuan filtrasi.

Variabel-variabel yang menjadi bahasan hanya terbatas pada variabel yang merupakan parameter pertumbuhan Chlorella vulgaris, yaitu $\mathrm{OD}_{600}$ yang akan diolah menjadi berat kering Chlorella vulgaris, $\mathrm{pH}$ yang dapat menunjukkan konsentrasi substrat, serta intensitas keluaran reaktor $\left(\mathrm{I}_{\mathrm{b}}\right)$ untuk mengetahui efisiensi energi cahaya yang digunakan untuk pertumbuhan.

$\mathrm{OD}_{600}$ diukur dengan Spectro UV-VIS $R S$ Spectrometre, LaboMed. Inc untuk mengetahui pertumbuhan Chlorella vulgaris di dalam reaktor. Basis kurva yang digunakan untuk mengolahnya menjadi berat kering merupakan kurva hasil penelitian sebelumnya. Intensitas cahaya yang diterima reaktor dan ditansmisikan keluar diukur dengan menggunakan Luxmeter. $\mathrm{pH}$ diukur dengan $\mathrm{pH}$-meter.

\section{Hasil dan Pembahasan}

Pada penelitian ini, digunakan inokulum awal dengan berat kering (X) 0.94 $\mathrm{mg} / \mathrm{dm}^{3}$ dengan intensitas cahaya yang diatur konstan yaitu sebesar 5000 lux serta dikultivasi dalam waktu 200 jam. Sebagai data pembanding maka dikultur pula Chlorella vulgaris dengan diberikan intensitas cahaya yang sama, volume yang sama, serta berat kering yang hampir sama $\left(0.935 \mathrm{mg} / \mathrm{dm}^{3}\right)$.

Perbandingan pertumbuhan berat kering Chlorella vulgaris antara reaktor yang menggunakan perangkap sel (X kontinufiltrasi) dengan yang tidak menggunakan perangkap sel (X kontinu) dapat dilihat pada Gambar 1. Dalam penelitian ini digunakan pencahayaan kontinu pada intensitas yang dijaga tetap. Itulah sebabnya pada kondisi kontrol, besarnya berat sel kering pada Gambar 1 dikatakan sebagai X kontinu.

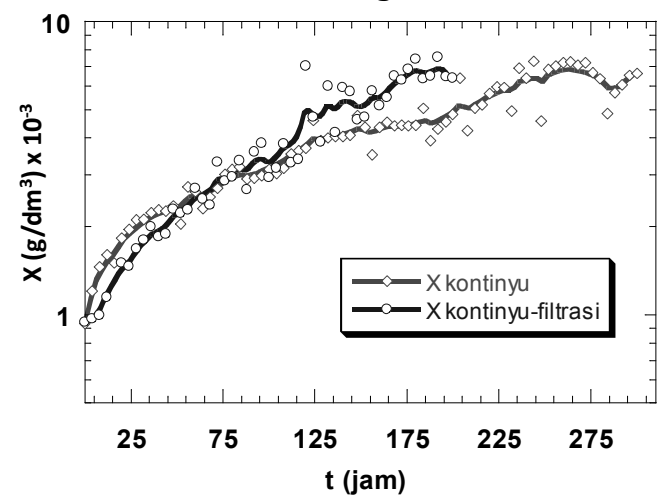

Gambar 1. Grafik perbandingan pertumbuhan Chlorella vulgaris pada reaktor berfilter dengan reaktor tidak berfilter

Pada grafik tersebut, dapat dilihat bahwa pada jam-jam pertama, pertumbuhan berat kering Chlorella vulgaris meningkat dengan pesat. Hal ini sesuai dengan kurva masa pertumbuhan Chlorella vulgaris dimana setelah fase lag (fase adaptasi) pada awal kultivasi, Chlorella vulgaris akan mengalami fasa pertumbuhan logaritmik dengan laju pertumbuhan yang maksimum. Seiring dengan waktu kultivasi, penambahan berat kering sel akan semakin berkurang karena telah memasuki fasa stasioner dimana terjadi penurunan metabolisme sel. Penurunan metabolisme sel disebabkan bertambahnya jumlah sel yang berarti kepadatan sel di dalam kultur semakin tinggi. Hal tersebut bisa menyebabkan self-shading sehingga mengganggu proses fotosintesis.

Tabel 1. Data Sel pada Akhir Kultivasi

\begin{tabular}{lccc}
\hline $\begin{array}{c}\text { Jenis } \\
\text { Reaktor }\end{array}$ & $\begin{array}{c}\text { X akhir } \\
\text { (mg/dm } \mathbf{3} \text { ) }\end{array}$ & $\begin{array}{c}\text { Berat } \\
\text { Kering } \\
\text { Mak- } \\
\text { simum }\end{array}$ & $\begin{array}{c}\text { Waktu } \\
\text { Kultivasi } \\
\text { (jam) }\end{array}$ \\
\hline $\begin{array}{l}\text { Reaktor } \\
\text { dengan }\end{array}$ & 6,39 & 7.56 & 200 \\
$\begin{array}{l}\text { Sistem } \\
\text { Filtrasi }\end{array}$ & & & \\
$\begin{array}{l}\text { Reaktor } \\
\text { tanpa }\end{array}$ & & & \\
Sistem & 6,34 & 7.31 & 300 \\
Filtrasi & & & \\
\hline
\end{tabular}

Dari tabel di atas, dapat dilihat bahwa penggunaan perlakuan filtrasi memberikan peningkatan terhadap biomassa yang dihasilkan sekitar 1,03 kali lipat 
dibandingkan dengan reaktor tanpa filtrasi, dengan waktu yang lebih singkat yaitu selama 200 jam dibandingkan dengan reaktor tanpa filtrasi yang memerlukan waktu selama 300 jam. Hasil tersebut disebabkan adanya perlakuan filtrasi yang dapat memerangkap sebagian produk biomassa dalam filter aliran sirkulasi kultur media. Filter tersebut lalu diambil setiap 12 jam sekali dan filtrat yang tersaring diperas dan disimpan.

Dengan adanya filtrasi, kepadatan sel di dalam medium dapat dikurangi, yang berarti peristiwa self shading dapat diatasi sehingga cahaya dan nutrisi yang diberikan tetap dapat diterima secara merata oleh Chlorella vulgaris di dalam kultur. Oleh karena mikroalga pada reaktor dengan filter mendapatkan cahaya dan nutrisi yang merata maka sel masih dapat melakukan proses metabolisme dengan baik sehingga biomassa yang terbentuk juga lebih besar.

Laju pertumbuhan Chlorella vulgaris pada media kultur seharusnya berada dalam fase logaritmik dimana laju pertumbuhan berada pada titik maksimal lalu seiring bertambahnya waktu akan terus menurun hingga memasuki fasa stasioner. Fenomena ini juga dapat dipahami dari persamaan yang digunakan untuk menentukan $\mu$, yaitu : (Schugerl dan Belgardt, 2000)

$\mu=\frac{1}{X} \cdot \frac{d X}{d t}$

Persamaan tersebut menunjukkan bahwa laju pertumbuhan berbanding terbalik dengan berat kering yang dihasilkan pada rentang waktu tertentu. Dari Gambar 2, terlihat bahwa terdapat kesamaan trend grafik antara reaktor dengan filtrasi dan tanpa filtrasi. Namun, pada masa awal kutivasi, laju pertumbuhan Chlorella vulgaris meningkat terlebih dahulu hingga laju pertumbuhan maksimumnya kemudian menurun hingga memasuki fasa stasioner. Hal itu menunjukkan bahwa sel pada awal kultivasi masih berada pada fasa lag (fasa adaptasi) dimana sel masih beradaptasi dengan mediumnya.Setelah itu, barulah sel tumbuh memasuki fasa log hingga stasioner.

Dari kedua gambar tersebut, juga dapat disimpulkan adanya perbedaan laju pertumbuhan maksimum pada awal kultivasi dimana laju pertumbuhan maksimum pada reaktor tanpa filtrasi sedikit lebih tinggi dibandingkan pada reaktor dengan filtrasi.
Hal ini disebabkan karena pada awal kultivasi, sel pada reaktor dengan filtrasi tersaring oleh filter padahal sel pada medium belum padat sehingga kemungkinan terlalu banyak sel yang terperangkap dalam filter.

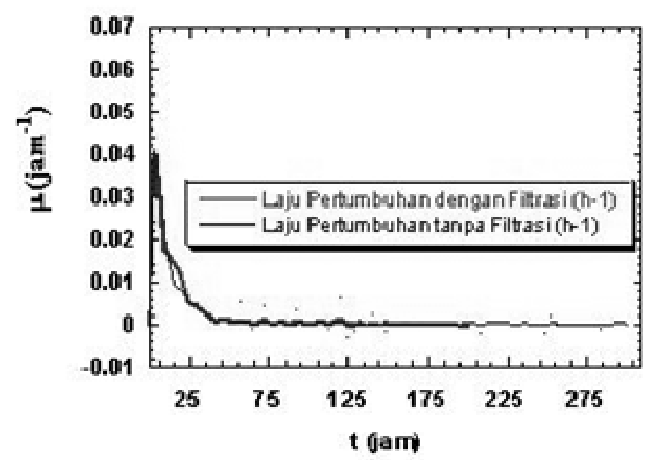

Gambar 2. Profil laju pertumbuhan sel $(\mu)$ pada reaktor dengan perlakuan filtrasi dan tanpa perlakuan filtrasi

Perkembangan yang baik mulai ditunjukkan pada jam-jam berikutnya. Pada periode waktu ini dapat dilihat bahwa laju pertumbuhan pada reaktor dengan filtrasi lebih baik dibandingkan pada reaktor tanpa filtrasi karena dengan kepadatan yang selalu dikurangi dengan adanya filter, tingkat kompetisi antar sel untuk memperebutkan nutrisi dan sumber pencahayaan jauh lebih rendah sehingga sel-sel mampu melakukan metabolisme secara maksimal. Hasil tersebut menunjukkan bahwa penggunaan reaktor dengan filtrasi untuk kultivasi Chlorella vulgaris memberikan laju pertumbuhan maksimum yang lebih rendah dibandingkan reaktor tanpa filtrasi pada masa awal kultivasi, namun secara keseluruhan laju pertumbuhannya lebih baik.

Perhitungan terhadap $\mathrm{HCO}_{3}$ - bertujuan untuk mengetahui konsentrasi $\mathrm{HCO}_{3}^{-}$yang tersedia, yang dapat dikonsumsi oleh sel Chlorella vulgaris untuk metabolismenya. Ion ini terbentuk karena adanya reaksi antara gas $\mathrm{CO}_{2}$ yang larut dalam medium dengan air. Konsentrasi $\mathrm{HCO}_{3}$ - dihitung dari perubahan pH kultur sebagai akibat adanya aktivitas pertumbuhan sel Chlorella vulgaris. Pada saat gas $\mathrm{CO}_{2}$ mengalir ke dalam kultur, proses yang terjadi adalah pembentukan senyawa bikarbonat seperti pada reaksi berikut (Pelroy dan Bassham, 1972).

$$
\mathrm{CO}_{2} \stackrel{+\mathrm{H}_{2} \mathrm{O}}{\longrightarrow} \mathrm{HCO}_{3}^{-}+\mathrm{H}^{+}
$$

Senyawa bikarbonat ini yang kemudian diserap oleh sel Chlorella vulgaris. 
Proses metabolisme yang terjadi dalam sel selanjutnya adalah reaksi antara senyawa tersebut dengan air yang terdapat dalam sel membentuk senyawa organik seperti glukosa dan air, seperti yang tergambar pada reaksi berikut ini : (Pelroy dan Bassham, 1972)

$$
\mathrm{H}_{2} \mathrm{O}+\mathrm{HCO}_{3}^{-} \stackrel{\text { Chlorella }}{\longrightarrow} \frac{1}{6} \mathrm{C}_{6} \mathrm{H}_{12} \mathrm{O}_{6}+\mathrm{O}_{2}+\mathrm{OH}^{-}
$$

Dengan menggunakan pendekatan hukum Henry, konsentrasi $\mathrm{HCO}_{3}{ }^{-}$dalam medium dapat diketahui. Besar nilai $\left[\mathrm{HCO}_{3}{ }^{-}\right]$ sebanding dengan nilai $\mathrm{pH}$ sehingga semakin besar nilai $\mathrm{pH}$ maka akan semakin besar pula nilai $\left[\mathrm{HCO}_{3}-\right]$.

Nilai pH mengalami kenaikan yang semakin tajam pada awal masa kultivasi hingga mencapai titik maksimum kemudian akan stabil pada akhir masa kultivasi. Fenomena ini terjadi karena pada awal kultivasi, sel masih sempat mengalami fasa lag (seperti yang sudah dijelaskan pada grafik laju pertumbuhan terhadap waktu) sehingga proses metabolisme belum terlalu maksimal yang ditandai dengan landainya peningkatan $\left[\mathrm{HCO}_{3}^{-}\right]$. Seiring bertambahnya waktu kultivasi, aktivitas pertumbuhan sel semakin tinggi (sudah berada dalam fasa eksponensial) sehingga proses metabolisme sel berlangsung maksimal. Hal tersebut ditandai dengan adanya peningkatan nilai $\mathrm{pH}$ (seperti yang tampak pada kurva) yang disebabkan bertambahnya ion $\mathrm{OH}^{-}$dalam medium.

Selanjutnya kenaikan nilai $\mathrm{pH}$ ini akan menurun seiring dengan berkurangnya aktivitas pertumbuhan sel. Hal ini juga berlaku untuk nilai $\left[\mathrm{HCO}_{3}^{-}\right]$dimana nilainya akan semakin naik karena konsumsinya semakin kecil akibat penurunan laju pertumbuhan sel sehingga terjadi akumulasi $\left[\mathrm{HCO}_{3}^{-}\right]$. Selain itu, kemampuan medium untuk melarutkan $\mathrm{CO}_{2}$ terbatas sehingga akan terjadi penjenuhan medium terhadap $\mathrm{CO}_{2}$ yang menyebabkan sejumlah ion bikarbonat yang terlepas akan kembali ke udara dalam bentuk gas $\mathrm{CO}_{2}$. Oleh karena peristiwa tersebut, konsentrasi $\mathrm{HCO}_{3}-$ dalam medium akan stabil.

Grafik konsentrasi $\mathrm{HCO}_{3}{ }^{-}$pada reaktor dengan filter (Gambar 3) menunjukkan pola yang lebih landai dibandingkan dengan grafik pada reaktor tanpa filter (Gambar 4). Konsentrasi substrat pada medium dalam reaktor dengan filtrasi pun lebih rendah

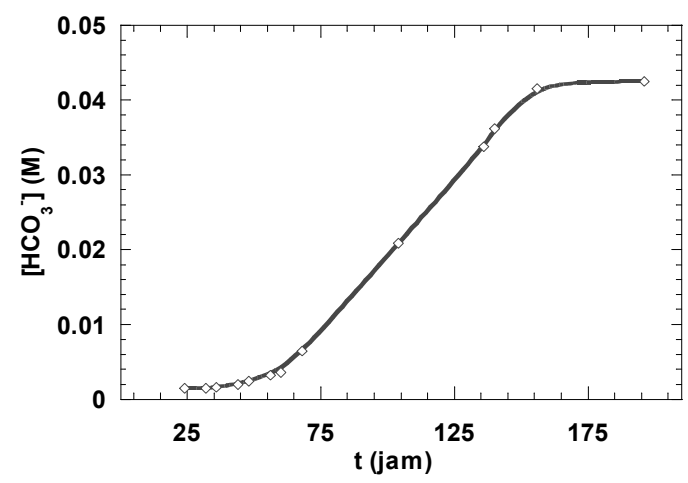

Gambar 3. Profil $\mathrm{HCO}_{3}^{-}$pada reaktor dengan filtrasi.

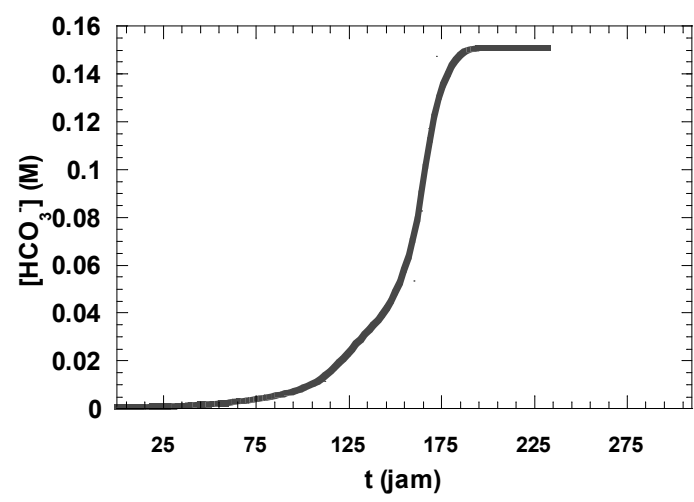

Gambar 4. Profil $\mathrm{HCO}_{3}^{-}$pada reaktor tanpa filtrasi.

dibandingkan dengan reaktor tanpa filter. Pada analisa sebelumnya, pengaruh filter pada produksi biomassa dan laju pertumbuhan Chlorella vulgaris menunjukkan hasil yang lebih baik dibandingkan dengan reaktor tanpa filter. Hasil tersebut seharusnya juga tergambar melalui aktivitas sel yang lebih baik namun nyatanya tidak tergambar melalui data konsentrasi bikarbonat dalam medium. Hal ini kemungkinan disebabkan karena grafik tersebut hanya menggambarkan kondisi substrat di dalam medium sedangkan setiap 12 jam sekali ada sebagian kultur yang terperangkap filter dipisahkan dari medium.

Dalam melakukan metabolisme, sel memerlukan cahaya sebagai sumber energi. Besarnya energi yang diperlukan untuk proses metabolisme sel sangat tergantung dari besarnya intensitas cahaya serta kondisi fotobioreaktor yang digunakan. Semakin besar intensitas cahaya yang digunakan maka produksi biomassa yang dihasilkan akan lebih baik sampai pada batas maksimumnya (Hirata dkk., 1996). Semakin baik kondisi fotobioreaktor maka semakin 
tinggi pula konversi energi cahaya untuk pembentukan biomassa.

Efisiensi konversi energi dapat dihitung dengan membandingkan antara besarnya energi yang dimanfaatkan untuk metabolisme dengan energi yang tersedia selama kultivasi. Baik energi yang dimanfaatkan maupun energi yang tersedia dapat diketahui dari besarnya intesitas yang ditransmisikan oleh reaktor dan intensitas cahaya awal yang masuk ke dalam reaktor. Tabel berikut adalah besarnya energi cahaya yang digunakan untuk produksi biomassa dari kedua jenis reaktor yang digunakan :

\section{Tabel 2. Energi Cahaya untuk} Produksi Biomassa

\begin{tabular}{lll}
\hline \multicolumn{1}{c}{ Jenis Reaktor } & $\mathbf{E}_{\mathbf{X}}(\mathbf{k J} / \mathbf{g})$ & $\boldsymbol{\eta}_{\mathbf{b p}}(\mathbf{\%})$ \\
\hline $\begin{array}{l}\text { Reaktor dengan } \\
\text { Filtrasi }\end{array}$ & 1.485 & 1.86 \\
$\begin{array}{l}\text { Reaktor tanpa } \\
\text { Filtrasi }\end{array}$ & 1.096 & 0.81 \\
\hline
\end{tabular}

Dari tabel tersebut, dapat dilihat bahwa efisiensi energi cahaya yang terjadi pada reaktor dengan filtrasi 2,3 kali lebih tinggi dibandingkan dengan reaktor tanpa filtrasi. Hal ini disebabkan karena efek selfshading yang lebih kecil pada reaktor dengan filtrasi sehingga distribusi cahaya lebih optimal. Ini juga diindikasikan dengan lebih besarnya cahaya yang ditransmisikan oleh sel pada reaktor dengan filtrasi dibanding reaktor tanpa filtrasi, yaitu sekitar 1,35.

Dengan demikian, dapat disimpulkan bahwa penggunaan reaktor dengan teknik pemerangkapan sel ini memberikan efisiensi konversi energi cahaya yang lebih baik.

\section{Kesimpulan}

Kesimpulan dari penelitian kultivasi Chlorella vulgaris dalam fotobioreaktor kolom gelembung dengan perlakuan teknik pemerangkapan sel dalam sirkulasi aliran media kultur adalah:

1. Perlakuan pemerangkapan sel pada sirkulasi aliran media kultur Chlorella vulgaris dapat meningkatkan produksi biomassa $(\mathrm{X})$ sebesar 1,03 kali lipat dibandingkan dengan biomassa yang dihasilkan pada kultivasi tanpa filtrasi dengan jumlah inokulum dan jenis pencahayaan yang sama (pencahayaan kontinu).
2. Perlakuan pemerangkapan sel menghasilkan peningkatan jumlah energi yang digunakan dalam kultivasi Chlorella vulgaris lebih besar sebanyak 1,35 kali.

3. Efisiensi pada reaktor dengan perlakuan teknik pemerangkapan sel pada sirkulasi aliran media kultur Chlorella vulgaris lebih tinggi 2,3 kali lipat dibandingkan dengan kultivasi pada reaktor tanpa sistem pemerangkapan sel.

\section{Daftar Pustaka}

Becker, W., Microalgae in human and animal nutrition, Handbook of Microalgae Culture: Biotechnology and Applied Phycology, Blackwell Publishing, Oxford, 2004, 312-351.

Hirata, S.; Taya M.; Tone, S., Characterization of Chlorella cell cultures in batch and continuous operations under a photoautotrophic condition, Journal of Chemical Engineering of Japan, 1996, Vol. 29 (6), 953-959.

Pelroy, R. A.; Bassham, J. A., Photosynthetic and dark carbon metabolism in unicellular blue green algae, Archives of Microbiology, 1972, Vol. 86(1), 25-38.

Pulz, O.; Scheibenbogen, K., Photobioreactors: Design and performance with respect to light energy input. Advances in Biochememical Engineering: Biotechnology, 1998, Vol. 59, 123-152.

Schugerl, K.; Belgardt, K. H. (eds), Chapter 2, Bioreaction Engineering, Springer-Verlag: Berlin, 2000, 44-102.

Wijanarko, A.; Dianursanti, H.; Heidi; Soemantojo, R. W.; Ohtaguchi, K., Effects of light illumination alteration on Chlorella vulgaris Buitenzorg's $\mathrm{CO}_{2}$ fixation in bubble column photobioreactor, International Journal on Algae, 2006, Vol. 8(1), 53-60.

Wijanarko, A.; Dianursanti; Andika, S. M. K.; Asami, K.; Witarto, A. B.; Ohtaguchi, K.; Soemantojo, R. W., Alteration of light illumination during microbial growth, an enhancement effort of Carbon dioxide fixation and biomass production by Chlorella vulgaris Buitenzorg, Abstract Book of $8^{\text {th }}$ International Conference on Carbon Dioxide Utilization, University i Oslo, Blindern Campus, Oslo, Norway, June 20-23, 2005, OC 06, 48-49. 
Peningkatan Produksi Biomassa (Dianursanti dkk.)

Wijanarko A.; Ohtaguchi, K., Alteration of light illumination during microbial growth: An enhancement effort of biomass production and carbon dioxide fixation of psychrophilic cyanobacterium Anabaena cylindrica IAM MI, Comparative Biochemistry and Phsiology, 2003, Vol. 134, S214.
Wirosaputro, S., Chlorella untuk Kesehatan Global, Teknik Budidaya dan Pengolahan, Gadjah Mada University Press, Yogyakarta, 2002. 